\title{
国際熱核融合実験炉 ‘ITER’の工学設計活動から建設へ
}

\author{
島本 進 ${ }^{* 1}$ 、高橋 良和 ${ }^{* 2}$ 、奥野 清 *3 \\ 'ITER'International Thermonuclear Experimental Reactor \\ - from the Engineering Design Activity to the Construction Phase-
}

\author{
Susumu SHIMAMOTO*1, Yoshikazu TAKAHASHI*2 and Kiyoshi OKUNO*3
}

\begin{abstract}
Synopsis: The purpose of this paper is to explain, from the aspect of the superconducting coil system, the concept of ITER (International Thermonuclear Experimental Reactor), which is to be constructed in France under the international collaboration of the seven parties. The specifications and results of research and development on the superconducting model coils, which was performed during the Engineering Design Activities, were compared with the final design of ITER. The identification of the relevance of model coils compared to full-scale ITER coils and related limitations are discussed from the technical and project management point of view.
\end{abstract}

Key words :fusion experimental reactor, superconducting coil, toroidal field coil, central solenoid coil, cryogenic structural material

\section{1. はじめに}

核反応を目的とした高温プラズマの閉じ込め法としては 磁界を利用した磁気閉じ込め方式が核融合開発の先端を歩 み、その中でもトカマク方式においてここ 10 年前から短 時間ではあるが核然焼が得られるとともに、この方式によ る核融合実験炉の設計 ${ }^{1-3)}$ がまとまった。この設計が可能 になった背景として、原研の JT-60 をはじめとする幾つか の大型装置によるプラズマ閉じ込め手法やその加熱手段の 進渉がある。他方、並行して進められた炉コンポーネン トの R\&Dによる目に見える工学の進歩と成果がある。し かし、実験炉であってもその建設には未踏分野が残ってい ることと、実験炉による燃焼研究を行った後に直ちに実 際の然料増殖や発電に進む状況ではないため、その建設 および実験研究は一国で賄うのは困難であると思われて いた。そこで、参加極（英語 party を極と呼ぶ）が資金を 出し合って一つの実験炉を建設することが提案され、設 計段階から国際協力により炉の名称を ITER（International

Received October 27, 2006

日本原子力研究開発機構那珂核融合研究所

干 311-0193 茨城県那珂市向山 801

Fusion Research and Development Directorate, Japan Atomic Energy Agency, Mukouyama 801, Naka, Ibaraki 311-0193, Japan

${ }^{* 1}$ 研究嘱託

Research Consultant

${ }^{* 2}$ ITER 国際チーム、那珂共同作業サイト

Staff of ITER International Team, Naka JWS

*3 ITER 超伝導磁石開発グループ・リーダー

Leader of ITER Superconducting Magnet Technology Group
Thermonuclear Experimental Reactor）としてその活動を進 めてきた。R\&D を含む工学設計活動の歩みの中でも種々 の紆余曲折を経て今日建設に着手するに至った。

磁気閉じ込め方式では、高磁界を発生する超伝導技術と 核融合炉との関係は非常に密接であり、実験炉建設コスト の四分の一強が超伝導コイルに費やされる。逆に、超伝導・ 極低温という専門分野においても、そこで核融合が占める 割合は同じく四分の一強と見られる。この状況を見つめつ つ日本原子力研究所 (“原研”、2005 年 10 月より日本原子 力研究開発機構 ‘原子力機構” ) は長年にわたってトカマ ク炉のための超伝導・極低温の技術開発 ${ }^{4)}$ を、企業・大学 と一致協力して推進してきた。そこには幾つかの独自のプ ロジェクト 5,6) および国際協力による作業 7,8) があり、段階 的に進展した技術が今日に至っている。

本文では、これまでの ITERの設計活動を概説し、ITER の内容に就いて超伝導・極低温の側面から紹介寸る。次に、 これまでの工学 R\&D として進められてきた成果と ITER の設計との関係を記し、更に国際協力による建設の作業分 担の模様を示す。これによって ITERの経緯と建設に立ち 向かう姿について広範囲の読者に理解を得ることを目的と している。他方、ITERの最初の活動が始まってから 20 年 近くを経過しており、担当者の世代交代も見られるので、 その間の理解を図ることも目的の一つとしている。

\section{ITER の概念設計から建設までの変遷}

ITER の第一歩である概念設計活動（CDA）は Table 1 に示すように 1988 年から開始された。この活動はドイツ のガルヒンク（ミュンヘン郊外）にあるマックスプラン 
Table 1 ITER の活動経緯とモデル・コイルの主な実験 The design activities of ITER and major testing of superconducting coil models.

\begin{tabular}{|c|c|}
\hline \multirow[t]{2}{*}{1988 年 4 月 } & : \\
\hline & 3 年弱 概念設計活動：CDA (Conceptual Design Activities) \\
\hline \multirow[t]{2}{*}{1990 年 12 月 } & 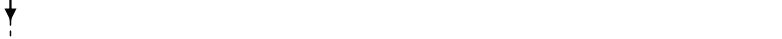 \\
\hline & EDA 協定の準備期間 \\
\hline \multirow[t]{4}{*}{1992 年 7 月 } & 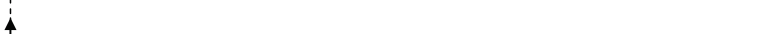 \\
\hline & 6 年間 工学設計活動：EDA (Engineering Design Activities) \\
\hline & 94 年 7 月 ITER ディレクターがレブー氏からエマール氏に交代 \\
\hline & 98 年 6 月末 98 年 ITER の設計報告書の提出 \\
\hline \multirow[t]{5}{*}{1998 年 7 月 } & EDA の 3 年延長 \\
\hline & 99 年 7 月米国が協定から脱退し、日・欧・ロの三極による継続 \\
\hline & 00 年 3 月から 8 月まで CS モデル・コイルの実験（那珂研） \\
\hline & 01 年 6 月カナダがクラリントンを候補地として提案 \\
\hline & 01 年 6 月末 ITER（建設決定）の報告書の提出 \\
\hline \multirow[t]{3}{*}{2001 年 7 月 } & 調整技術活動：CTA (Coordinated Technology Activities) \\
\hline & T 02 年 6 月日本は六ヶ所村、欧州はカダラッシュを候補地として提案 \\
\hline & 02 年 8 月から 12 月まで TF モデル·コイルの実験 (カールスルーエ研) \\
\hline \multirow[t]{6}{*}{2002 年 12 月 } & 移行措置: ITA (ITER Transition Arrangements) \\
\hline & 03 年 2 月米国が ITER に復帰、中国参加 \\
\hline & 03 年 6 月韓国参加 \\
\hline & 05 年 6 月 28 日サイトをカダラッシュに決定 \\
\hline & 05 年 12 月インド参加、ITER 協定文案まとまる、調達案決定 \\
\hline & 06 年 5 月 ITER 協定の七極による仮調印（ブラッセル） \\
\hline 2006 年 11 月 & 06 年 11 月 21 日にパリで協定の正式調印 \\
\hline
\end{tabular}

ク・プラズマ物理研究所内にオフィスを設け、そこに欧・ 米・ソ・日の四極から専門家が集ってチームを編成し 3 年 弱の期間で実験炉の概念を固めた。これに引き続く活動と して 1992 年から 6 年間で、建設を考慮した工学設計活動 （EDA）を上記四極が、ハードウエアの詳細設計とこれに 対応する炉コンポーネントの工学 R\&D を実施した。当初 は EDA 終了後直ちに建設作業に入ることを前提としてい た。EDAの共同設計チームは四極の専門家から編成され、 そのオフィスは偏りを避けるために欧・米・日の三力所に 分割された。設計作業はコンピュータ・ネットワークで結 んで進められた。共同設計チームはその後ろ盾になってい る各極のホーム・チームと緊密な連絡を取りつつ、夫々 の専門別に会合を開き、時には各専門の代表メンバーで全 体の調整を行って設計を進めた。建設を目指す EDA の大 きな特色は設計と並行して炬コンポーネントの工学 R\&D を実施したことである。EDA が開始される前後に行わ れた交渉によって、各極の担当する項目が決まった。こ の R\&D については後に記述する。このような経過の中、 $\mathrm{EDA}$ 開始 2 年後の 1994 年 7 月に共同設計チームの指揮者 であるダイレクターの交代が突如あり、これに伴って後に 一部設計変更もあった。EDA 開始前後にはソ連が崩壊し、 国土之社会構造の異なったロシアに替わる出来事があった が、この極が入れ替わる過渡期には残りの三極がプロジェ クトを支えた。

当初のスケジュールに従って 1998 年 6 月末に設計報告 書がまとめられ、この時の設計は 1998 年 ITER（98'ITER） と呼ばれることがある。この 1998 年 ITER ${ }^{9}$ は、自己点火
の達成を目指した実験炉としてサイズを大きく取り核燃焼 に余裕を持たせたが、そのため建設費がかさみ国際協力 といえどもその建設を社会一般に説得できるものではなか った。従って、小型化を目的とした設計変更を行うために 1998 年 7 月から EDA の協定が 3 年間延長された。

この設計変更を見て、核融合開発に疑問を持った米国 は延長 1 年目の 1999 年 6 月末で EDA の活動から脱退した。 それまで進めてきた工学 R\&D は八ードウエアの製作とそ の作動実験であるので、当初の活動終了時期である 1998 年 6 月時点で完了していないものが多く、延長に当たって これを継続して目的を達成することについては四極ともに 異論はなかった。しかし、米国が脱退したことにより、米 国の研究者は継続している R\&D の実験に参加して情報を 得ることさえも不可能になりかけた。そこで残る三極は将 来のことを考慮して、米国の研究者がその後も引き続いて 実験に参加する場合には、それぞれに存在する核融合に関 する二国間協定を適用してその道を残した。

3 年間延長した満期の 2001 年 6 月末には設計を大幅に 変更した報告書が出され、これが今日建設する内容として 確定している ITER である。しかし、この報告書が出され た時点でも各極から建設サイトの提示がなく、先に進める 状況ではなかったので欧・ロ・日の三極によって調整技術 活動（CTA）に入った。この前後に建設サイトの提示が始 まり、カナダが最初にクラリントン（トロント近郊）を示 した。

2002 年に入り日本は青森県六ヶ所村を、欧州はフラン スのカラダッシュ（南仏のエキサンプロバンス近郊）を提 


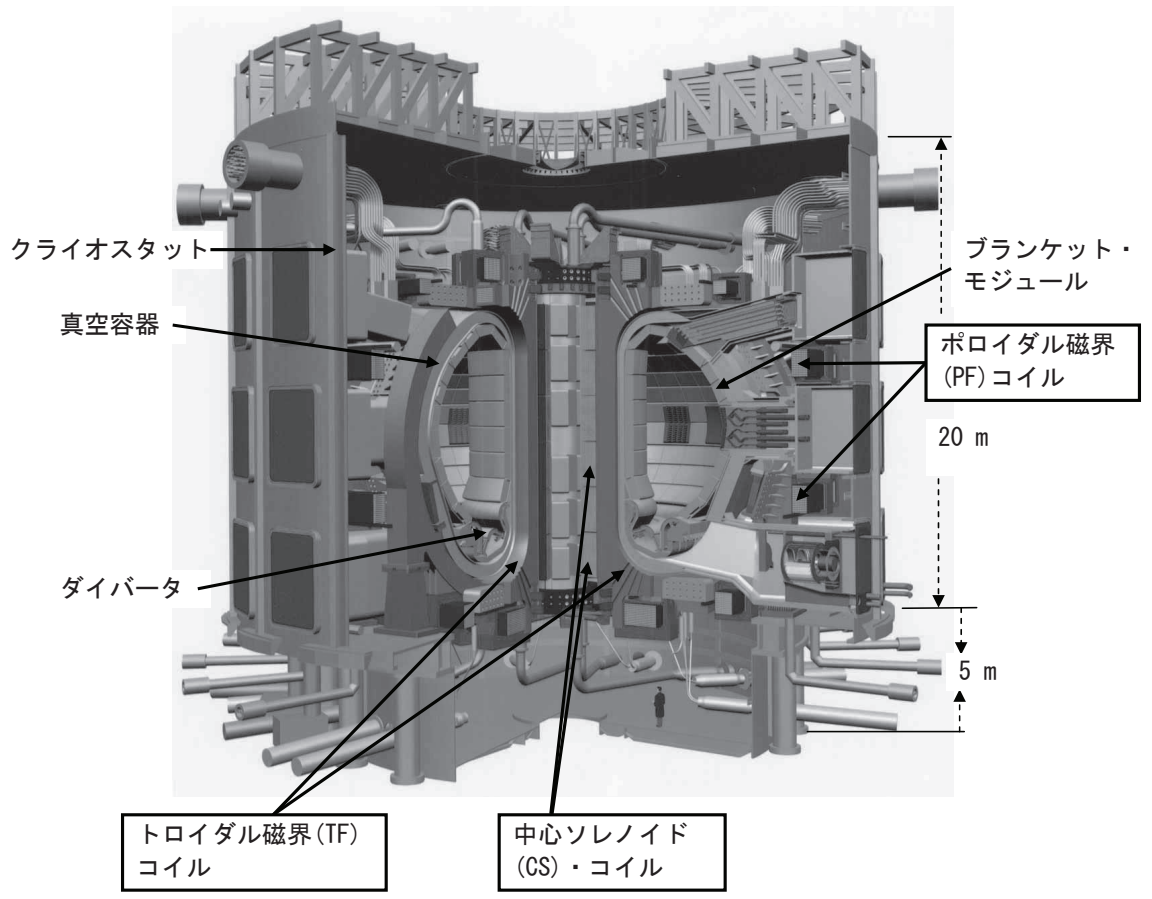

Fig. 1 建設する ITER の炉心 : CS コイルは同一サイズのもの計 6 個。TF コイルは同じく計 18 個。 $\mathrm{PF}$ コイルは計 6 個（赤道面に対してアンペア・ターンおよび位置は上下対称でない）外界との 断熱壁はクライオスタットであり、プラズマとの断熱壁が真空容器である。

Reactor core of the ITER to be constructed. Toroidal field coil: 18 coils of the same size; Central solenoid coil: 6 sub-coils of the same size; Poloidal field coil: 6 large coils, each with different diameters; Cryostat: barrier between reactor core and outside; Vacuum vessel: barrier between plasma and coil system.

案した。サイト交渉をさらに続けて ITER を建設に持ち込 むために三極は 2002 年 12 月から移行措置（ITA）という 期間を設けた。建設の気運が見えてきたところで、米国が 2003 年 2 月に ITER の活動に復帰し、これと同時に中国が 参加した。2003 年 6 月には韓国が追って参加した。2005 年 6 月には建設サイトはカラダッシュに決定した。この年 12 月には協定の文案が完成し、同じ頃にインドが ITER に 加わって総勢七極となるとともに、各極からのハードウェ ア調達案が決まった。2006 年 5 月に七極による協定の仮 調印が行われ、同年 11 月に本調印が終了した。振り返る と EDA の当初から 14 年という非常に長い道のりであっ た。それは研究・設計・開発が障壁で立ち往生立したこと によるものではなく、核融合開発が長期間にわたる課題で あるがために各国の財政状況や政策的課題に左右されて先 送りになったのである。またエネルギーの逼迫という緊張 もなく過ぎてきたので、緊急な開発も迫られなかったこと もその一因と見られる。

\section{3. 建設する ITER の内容 ${ }^{1-3)}$}

ITER 本体であるクライオスタットの一部分を切り取っ た炉心構造は Fig. 1 に示寸ものである。断熱真空を保持す るクライオスタットの直径は $28 \mathrm{~m}$ 、高さは $25 \mathrm{~m}$ であり、 図下部右寄りにある人の姿からその大きさを察することが できる。ITERの磁界発生コイルはすべて超伝導で、3種
の超伝導コイルは矢印で示すように配置されている。他に、 もう一種規模の小さい補正コイルがあるが機器の陰になり この図では見えない。プラズマ閉じ込めのためのトロイダ ル磁界（TF）コイルは直流通電により定常磁界を発生し、 主要な超伝導コイルの一つである。その内側にはプラズマ が入る真空容器が設置されている。この真空容器の中には 高熱負荷に耐えるプラズマ対向壁を取り付けたブランケト やダイバータがある。実験炉である ITER のブランケット は、中性子遮蔽と放熱のみを行う遮蔽ブランケットである が、その一部にはデモ・ブランケットと呼ばれるトリチウ ム増殖を模擬できるものが取り付けられる。真空容器本体 の重量は 5,500 t、超伝導コイルの合計重量は $10,000 \mathrm{t}$ で、 その $60 \%$ が TF コイルである。クライオスタットと複雑な 配管の重量を加えると全体として巨大な重量物であること が分かる。クライオスタットを収納する部屋は中性子遮蔽 の隔壁で取り囲まれている。この本体室を取り囲んで隣接 する部屋にはトリチウム注入 ・回収装置、中性粒子入射装 置、高周波発生装置、クライオポンプ装置等がある。更に その遥か後方には超伝導コイル用電源、中性粒子用電源、 高周波用電源、ヘリウム冷凍機に加えて、別に巨大な冷却 塔がある。つまり、本体はこれらの支援装置の機能が集約 されるところと見なすこともできる。

ITER の物理・工学の主要なパラメータを Table 2 に示す。 核融合出力は $500 \mathrm{MW}$ で燃焼時間は 400 秒である。この 
Table 2 ITER の活動経緯とモデル・コイルの主な実験 Major parameters of ITER

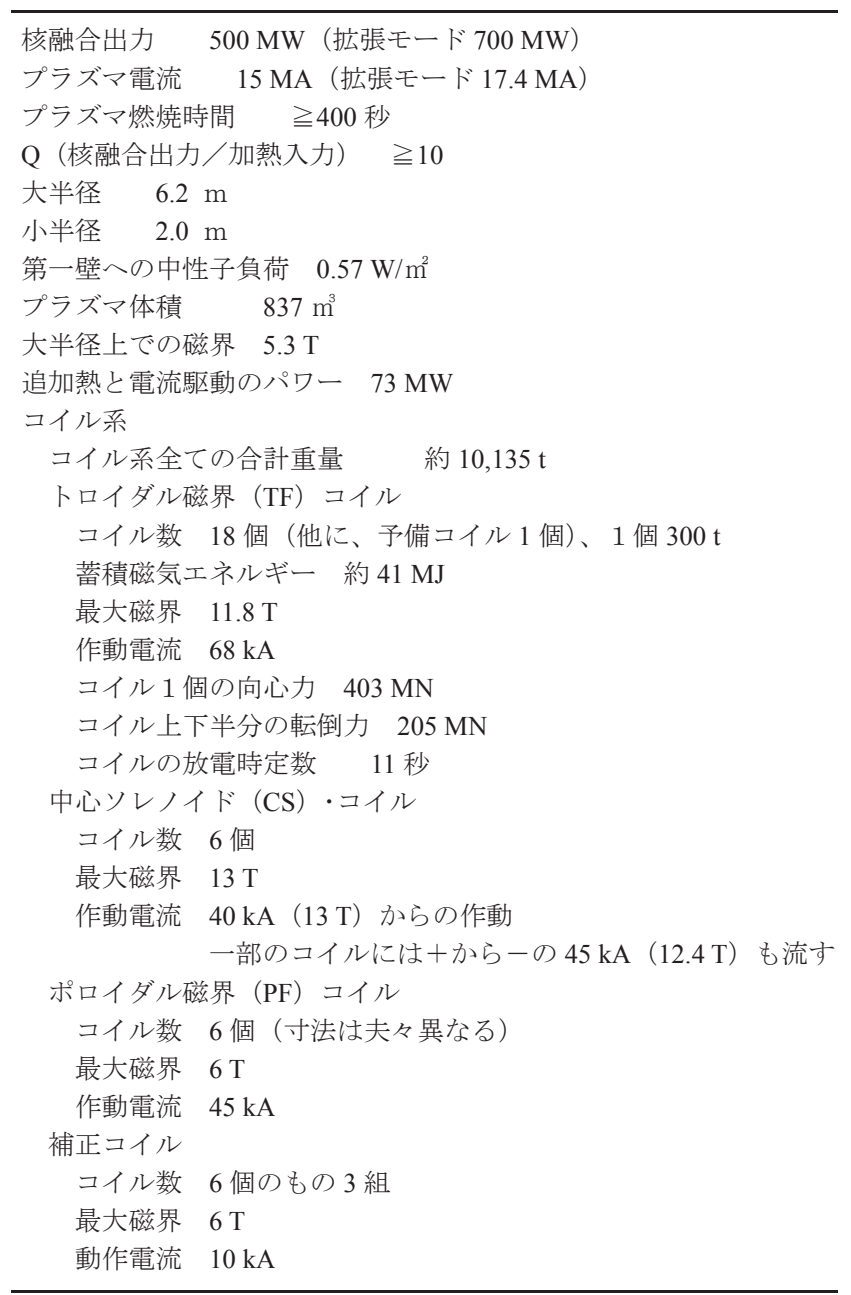

出力は遮蔽ブランケットを介し熱として放出するので、運 転サイクルが速い場合には大量の冷却水を必要とする。従 つて、冷却水の供給能力が建設サイトの重要な条件の一つ となっている。この設計では 1998 年 ITERから全体の寸 法を小さくしたので、プラズマの加熱入力エネルギーに対 する出力の割合を示す Q の值も、1998 年 ITER では自己
Table 3 ITER の CS コイル導体と TF コイル導体の仕様 Specification of ITER CS coil conductor and TF coil conductor

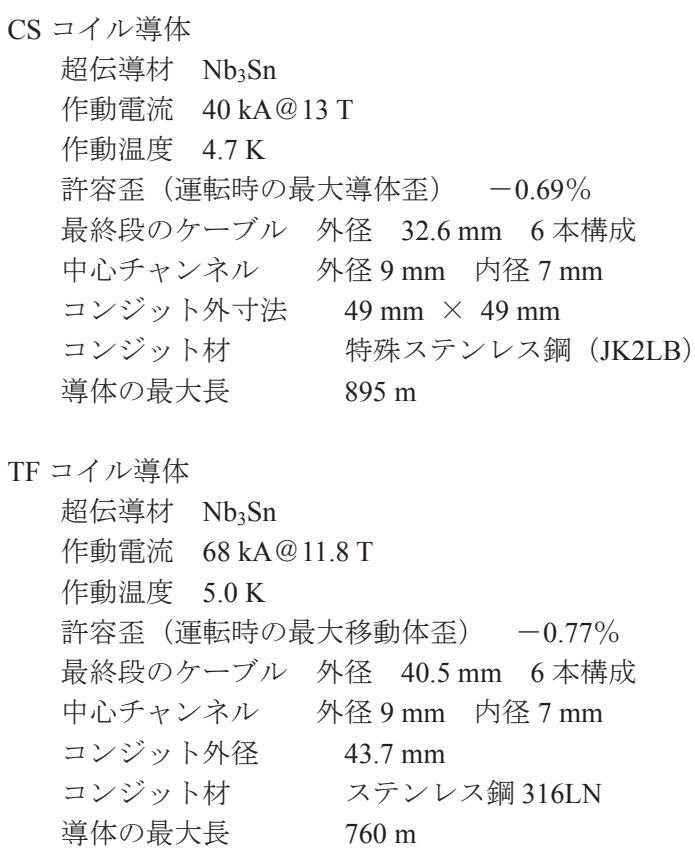

点火条件として無限大であったのを譲って 10 に下げ、機 器の熱的定常を保てる時間を確保した。

重要な超伝導コイルとして、上記の TF コイルの中央に 配置される中心ソレノイド（CS）コイルがある。このコ イルは変流器の一次巻線であり、二次巻き線に対応寸るプ ラズマの点火とその電流を変流する役目をしている。CS コイルと $\mathrm{TF}$ コイルの超伝導導体の仕様は Table 3 に示す ものである。この両コイルの発生磁界は $13 \mathrm{~T}$ に及ぶので 超伝導材料として化合物である $\mathrm{Nb}_{3} \mathrm{Sn}$ を使用する。これ らに使用される $\mathrm{Nb}_{3} \mathrm{Sn}$ 素線の仕様は材料の製造方法に従 って異なり、両者を Table 4 に示す。CS コイルは 0.4 T/s のパルス作動という条件で運転されることがその特徴であ る。

CS コイルはパルス磁界による誘導電流を避けるために

Table 4 ITER の $\mathrm{Nb}_{3} \mathrm{Sn}$ 素線の仕様

Specifications of ITER $\mathrm{Nb}_{3} \mathrm{Sn}$ strand

\begin{tabular}{|c|c|c|c|c|}
\hline & \multicolumn{2}{|c|}{ CS コイル導体の素線 } & \multicolumn{2}{|c|}{ TF コイル導体の素線 } \\
\hline & ブロンズ法 & 内部拡散法 & ブロンズ法 & 内部拡散法 \\
\hline $\begin{array}{l}\text { 臨界電流密度 } 12 \mathrm{~T}, 4.2 \mathrm{~K} \\
0.1 \mu \mathrm{V} / \mathrm{cm} \text { (外部歪なし) }\end{array}$ & $>750 \mathrm{~A} / \mathrm{mm}^{2}$ & $>850 \mathrm{~A} / \mathrm{mm}^{2}$ & $>700 \mathrm{~A} / \mathrm{mm}^{2}$ & $>800 \mathrm{~A} / \mathrm{mm}^{2}$ \\
\hline ヒステリシス損失 $\pm 3 \mathrm{~T}$ 銅以外の部分 & \multicolumn{2}{|c|}{$<700 \mathrm{~mJ} / \mathrm{cm}^{3}$} & \multicolumn{2}{|c|}{$<1,000 \mathrm{~mJ} / \mathrm{cm}^{3}$} \\
\hline 素線直径 & \multicolumn{2}{|c|}{$0.83 \mathrm{~mm}$} & \multicolumn{2}{|c|}{$0.82 \mathrm{~mm}$} \\
\hline $\mathrm{n}$ 值 $12 \mathrm{~T}, 4.2 \mathrm{~K}, 0.1 \sim 1.0 \mu \mathrm{V} / \mathrm{cm}$ 間 & \multicolumn{4}{|c|}{$>20$} \\
\hline 銅と非銅部分の比率 & \multicolumn{4}{|c|}{1} \\
\hline 右巻きのツイスト・ピッチ & \multicolumn{4}{|c|}{$15 \mathrm{~mm}$} \\
\hline 製造する単位長 & \multicolumn{4}{|c|}{$>4 \mathrm{~km}$} \\
\hline 銅の残留抵抗比 & \multicolumn{4}{|c|}{$>100$} \\
\hline 表面のクロム鍍金の厚み & \multicolumn{4}{|c|}{$1 \sim 2 \mu \mathrm{m}$} \\
\hline 最終段階熱処理条件 & \multicolumn{4}{|c|}{$650^{\circ} \mathrm{C} \sim 200$ 時間 } \\
\hline
\end{tabular}




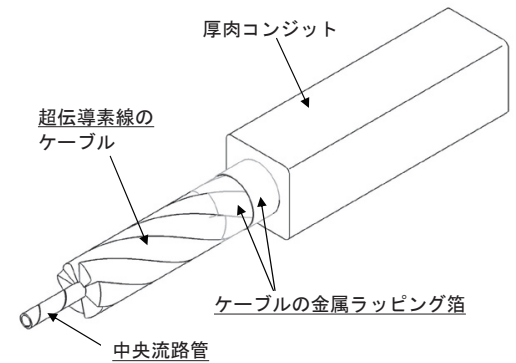

Fig. 2 ケーブル・イン・コンジット導体の概念構造 : 図は $\mathrm{CS}$ コイル導体と PF コイル導体の例を示しているが、そ れぞれによって寸法等が異なる。 $\mathrm{TF}$ コイル導体では図の 肉厚コンジットの代わりに、薄肉円管を用いる。

Concept of a cable-in-conduit conductor. The figure shows an example of a CS coil conductor or PF coil conductor, which are different in size and material. In a TF coil conductor, a thin circular conduit is used instead of a thick rectangular conduit.

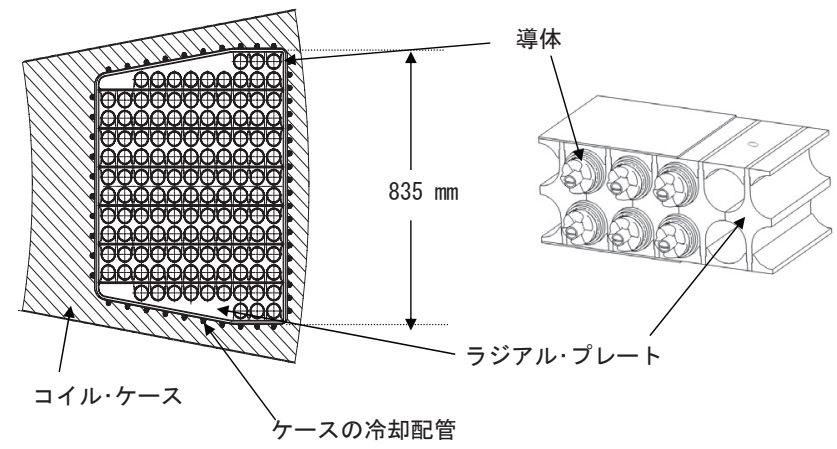

Fig. $3 \mathrm{TF}$ コイルの断面 (左) とその内部構造 (右) : ラジ アル・プレートに入る導体は薄肉の円筒コンジットに入っ ている。

Cross section of the TF coil (left) and bird's-eye view of the inside (right): the each conductor has thin tubular couduit on the outside.

コイル・ケースはなく、その代わりとして導体に厚肉のコ ンジットを持たせているケーブル・イン・コンジット導体 である。その構造は Fig. 2 に示すものである。コンジット の外寸法は $5 \mathrm{~cm}$ である。これに対し TF コイルでは、導 体の基本構造は同じであるが CS コイル導体の厚肉コンジ ットの代わりに薄肉円管をコンジットとしてそこでへリウ ムの気密を持たせて、電磁力支持はこの導体を納めるラジ アル・プレートで行う。更に、このラジアル・プレートを まとめて厚肉のコイル・ケースに入れて全体の剛性を高め る。 $\mathrm{TF}$ コイルの断面構造とラジアル・プレートを含めた 導体部の立体構造とを Fig. 3 に示す。

上記の 2 つコイルとは別に、円環状のプラズマがそ の直径を外部に膨らませようとするのを押し返す磁界を 発生するのが径の大きなポロイダル磁界（PF）コイルで、 これは TF コイルの外部に配置される。PF コイルの電流は プラズマの変位に対応してゆっくり変えられる。ITERで はサイズの異なった 6 個の PF コイルがある。PF コイルで は最大磁界が $6 \mathrm{~T}$ と比較的低いので、超伝導材料として合

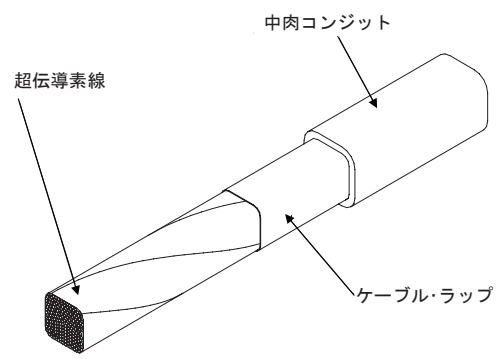

Fig. 4 補正コイルの 2 種類ある導体の一方（中心流路のな いもの)

One of two types correction coil conductors (without a central channel).

金である $\mathrm{Nb}$-Ti を使用する。従って、巻線後の熱処理を必 要としないが最大直径は $20 \mathrm{~m}$ を超すので ITER の建設現 場での巻線作業となる。PF コイルの最大電流は $45 \mathrm{kA}$ で あり、誘導電流を避けるために CS コイルと同様にコイル・ ケースはなく導体は Fig. 2 の構造と類似であるが、超伝導 材料と導体寸法が異なっている。その重力と電磁力は全て $\mathrm{TF}$ コイルに持たせているので、構造的には TF コイルと $\mathrm{PF}$ コイルは一体物になっていると考えてよい。

先に触れた補正コイルは TF と PF コイルの幾何学的配 置のズレによる誤差磁界を補正するものであり、6 個のコ イル 3 組で構成される。最大電流值は $10 \mathrm{kA}$ 、最大磁界は 約 $4 \mathrm{~T}$ であり、 $\mathrm{Nb}-\mathrm{Ti}$ を使用する。導体構造は中央流路の ある PF コイル導体の縮小型と流路のない導体と二種類あ る。Fig. 4 は後者の構造を示しており、一辺は $2 \mathrm{~cm}$ である。 全てのコイルはクライオスタットを外壁とする断熱真 空空間に配置されており、これらの導体内部に超臨界圧へ リウムを流すことにより極低温を維持するのでヘリウム貯 槽は無い。

\section{EDA（工学設計活動）における工学 R\&D と超伝導 コイルに関する成果}

\section{1 七大工学 R\&D とその他の $R \& D^{9,10)}$}

工学 R\&D の費用は、本体の設計活動費とは別に、1992 年に四極による 6 年間の合計で円換算にして 1,000 億円と 決まった。従って、一極当たり 250 億円である。共通資金 は作らずに、交渉によって決めた作業分担に従って各極が 自極の予算から対応した費用を直接使用する形を取った。 主要な R\&D は七大工学 R\&D と呼び、四極の中から幹事 極と実施機関を決め、実施機関は大型の工学実験設備を設 置する作業を行った。その実験サイトには複数の参加極が 製作したものを持ち込み、それらを互いに組み合わせ、あ るいは入れ替えて実験研究を行う方式を取った。これは 次に予定している ITER を国際的に建設するトレーニング の意味があった。七大工学 R\&D では Table 5 に示すよう に当初から重要度に従って序列が付けられ、その費用は上 
Table 5 EDA における七大工学 R\&D の内容

Contents of the seven major engineering research and development projects in the EDA

\begin{tabular}{|c|c|c|c|}
\hline 重要度の順位 & R\&D 項目 & 幹事極 & 実施機関と場所 \\
\hline 1 & CS モデル・コイル開発 & 日本 & 日本原子力研究所 \\
\hline 2 & $\mathrm{TF}$ モデル・コイル開発 & 欧州 & $\begin{array}{l}\text { EFDA (European Fusion Development } \\
\text { Agreement)、カールスルーへ研究所 }\end{array}$ \\
\hline 3 & 真空容器の $1 / 20$ セクタ試作 & 日本 & 日本原子力研究所 \\
\hline 4 & ブランケット・モジュール開発 & 欧州 & EFDA、場所は欧州内に分散 \\
\hline 5 & ダイバータ・カセット開発 & 米国 & $\begin{array}{l}\text { サンディア国立研究所 } \\
\text { マクダネルダグラス社 }\end{array}$ \\
\hline 6 & ブランケット・モジュール遠隔保守技術開発 & 日本 & 日本原子力研究所 \\
\hline 7 & ダイバータ・カセット遠隔保守技術開発 & 欧州 & イタリア原子力研究所 \\
\hline
\end{tabular}

記の全費用の $50 \%$ を投入するという力の入れ方であった。 Table 5 から分かるように、超伝導コイルでは CS コイルが 技術的に難しいこととその成否が実験炉の鍵になるという ことで TFコイルよりもランクが高くなっている。この表 から超伝導コイルを他のコンポーネントと比較した場合の 重要度を客観的に把握できると思う。

日本はCS コイル以外に $1 / 20$ セクタ（円周の 18 度分） の真空容器とブランケット・モジュール交換の遠隔操作シ ステムを担当し、真空容器と遠隔操作システムを合体して 操作実験を実施し当初目的を立派に達成している。

上記七大工学 R\&D の他に規模の小さい R\&D 項目が数 多くある。それらは極の間で作業が重複しないように尚か つ一極の予算枠を超えないように調整され、これらの実験 現場を他極に開示し得られた成果は報告書としてまとめて 四極で共有することで進められた。その一例としては後に 記述する日本が担当した低温構造材料の評価試験がある。

\subsection{CS モデル・コイルの R\&D}

R\&D で重要度が高い超伝導コイルは ITER の構造シス

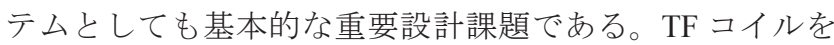
励磁すると 18 個のコイルは自律的に中心軸に向かう向心 力を発生する。この向心力を保持する方法は次の二案が ある。一つは TF コイルの直線部分の両側面を楔状に削り お互いの楔面が接触することにより $\mathrm{TF}$ コイル同士で向心 力を持たせる案である。この場合には、中心に置かれる $\mathrm{CS}$ コイルは TF コイルと構造的に独立したものとして設 置できる。もう一つの方法は TF コイルの集合した中心に バックキング・ポストと呼ばれる構造物を設け、 $\mathrm{TF}$ コイ ルの向心力をこれで支持するという案である。1992 年に 共同設計チームの初代ダイレクターとして就任したレブー (Rebut) 氏は、CDA で残された技術的課題を解決するため、 各所に個性的な設計を主張した。TF コイルの向心力支持 に関しては、バッキング・ポスト方式を発展させ、TFコ イルを CS コイル外周に接触させることで $\mathrm{TF}$ コイルの向 心力と CS コイルに発生する巻き線の拡大力とをバランス させるという奇抜なアイディアを盛り込んだ。TFコイル
の面外力に対する剛性力を高めるため、一般的製作手法と してパンケーキ巻を考える所をレイヤー巻きとしてシェ ア・パネルというステンレス板の溝に導体を納め、そのパ ネルを層状に重ねてコイルとするコイル・ケースの無い構 造とした。しかしながら、これらはそれまで製作の手順や 品質管理から積み上げてきた超伝導コイルの設計手法を無 視したもので、多くの議論を巻き起こした。このアイディ アによって、CS コイルはその外側に突出物を持たないよ うにレイヤー巻の一体ものとなった。CS コイルを軸方向 に分割して励磁することは運転シナリオの柔軟性に意味が あるが、結果としてこれも不可能になった。この点につい ても多くの専門家との意見の食い違いがあったが、全ての 設計はダイレクターの強い指揮で進められた。EDAでは、 工学 R\&D は設計する実機の縮小モデルを作りその技術的 実証を行うという方針であった。これに準じて共同設計チ 一ムは CS モデル・コイルをレイヤー巻きとして指示した。 CS モデル・コイルについては日本が幹事極であるという 立場から、日本のホーム・チームはモデル・コイルの円筒 長さの半分はレイヤー巻として残り半分はパンケーキ巻き とすべきであると提案したが、合意は得られなかった。日 本の提案は、大量の $\mathrm{Nb}_{3} \mathrm{Sn}$ を用いてメートルの桁の空間 に $13 \mathrm{~T}$ を発生させることは初めての大きな挑戦であるの で、品質管理を行いやすくして部分的に交換可能なパンケ 一キ巻きの技術にも道を作っておくべきという主張であっ た。そして、R\&Dの成果を見た後に建設を決める時点で 巻き線方式を見直す余裕は十分にあると判断した。しかし、 $\mathrm{CS}$ モデル・コイルも大きなプロジェクトであり時間的な 逼迫もあったので一歩蚊って、総てレイヤー巻きとするこ とを受け入れて作業を開始した。その後にダイレクターに 就任したエマール（Aymar）氏は、1998 年 ITERの TF コイ ルをパンケーキ巻きにしてコイル・ケースも付けることに 変更したが、CS コイルについては前任者のものを踏襲し た。実機設計の変更が有ろうと無からうと、この時点では 既に走り出していた CS モデル・コイルの内容を変更する ことは不可能であった。エマール氏はその後の ITER 小型 
化設計に当たって大きな変更を行い、CS コイルは全体を 軸方向に 6 個分割してそれぞれをパンケーキ巻きとした。 これによって通電も個別に行える柔軟な運転シナリオがで きた。更に、 $\mathrm{TF}$ コイルの向心力を楔構造で相互に持たせ るようにし、万一の場合に CS コイルを軸方向に引き抜け るようにした。これらは当初から日本のホーム・チームが 主張していたことであり、EDA 開始から 10 年の歳月をか けてようやく意見の一致を見ることができた。

$\mathrm{CS}$ モデル・コイルの R\&D 目標は大口径に $13 \mathrm{~T}$ の発生 とそのレベルでの $0.4 \mathrm{~T} / \mathrm{s}$ のパルス運転のデモンストレー ションである。それまで $\mathrm{Nb}_{3} \mathrm{Sn}$ による $10 \mathrm{kA}$ のパルス用 導体による $8 \mathrm{~T}$ パンケーキ・コイルの作動実績は原研 ${ }^{11}$ にしかなかった。しかし、ITERの目標はこれから遥かに 遠い未踏の領域であったため、それまでの経験があっても 開発現場は多くのことに挑戦しなければならなかった。代 表的な技術的課題は、 $\mathrm{Nb}_{3} \mathrm{Sn}$ による大電流導体の設計とり わけパルス損失と超伝導安定性の両立、ITERの協力精神 に従って半加工品で種々の国を行き来して最終製品とする ことの品質保証、コンジット導体内における素線間の偏流 現象 ${ }^{12)}$ によるクエンチ（常伝導転移）を回避することで あった。パルス損失と超伝導安定性の両立性についての基 本的研究は、それまで原研と欧州の一部で進められてい ただけである。CS モデル・コイルは実機と同じ構造の 46 $\mathrm{kA}$ と大電流に決まったので、その縮小導体による超伝導 実験および実規模での短尺導体製作を行うなど、予備的か つ段階的な開発が進められた。導体の半加工品が国境を越 えて次の国で新たな加工作業を行うことは免税措置の手続 きに手間ひまを要した以外に、取り合い点での品質管理や 納入遅れによる工程への影響に頭を痛めたことを思い浮か べられる。製作過程でのテーマとして、導体の熱処理過程 におけるコンジット材である INCOLOY908 の SAGBO（応 力酸化粒界割れ）の発生 ${ }^{23)}$ は、予見はしていたものの数 百メートルにおよぶ長尺物でこれを回避できるか大きな課 題であった。しかし、原研が行った試行錯誤によって、コ ンジット材の歪除去と熱処理雰囲気の酸素濃度を厳格に管 理することで問題の解決ができた。他方、超伝導電流の 偏流現象 ${ }^{12,13)}$ については、最終通電になって初めて表面 化してくるものなのでリスクの大きい課題であった。こ れに対してそれまでの研究を外挿して考え、素線にクロム 鍍金を施し電流が素線間を移動しやすくすることによっ てそのクエンチの回避を期待した。これを裏付ける小規模 実験や解析を各極が協力して実施した。その結果、それ まで偏流による顕著なクエンチを経験している Nb-Ti（原

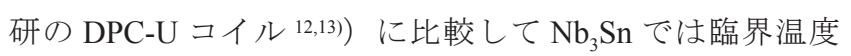
までのマージンが大きいために偏流によるクエンチの可 能性は低下すると判断された。クロム鍍金は偏流に対す る完全な定量的かつ能動的管理でない上に、大電流化の ためにこれまでよりも多い素線導体数と導体長とを考え
Table 6 那珂核融合研究所で実験を行った CS モデル・コ イルとそのインサート・コイル 3 個

The CS model coils and three insert coils tested at Naka Fusion Res. Est. of JAERI

1. CS モデル・コイルとCS インサート・コイル（日米欧担当、厚肉コンジッ トと $\mathrm{Nb}_{3} \mathrm{Sn}$ を使用した中心ソレノイドのモデル)

1-1. 日本が担当した CS モデル・コイルの外層モジュール（低磁界領域） コイル到着: 1998 年 11 月 11 日

1-2. 米国が担当した CS モデル・コイルの内層モジュール（高磁界領域） コイル到着: 1999 年 5 月 13 日

1-3. 日本が担当した CS インサート・コイル（1 層コイル、13 T の実証目的） コイル到着: 1999 年 5 月 21 日

上記 3 つのコイルを一体に組み合わせて $13 \mathrm{~T}$ とそのパルス作動実験 予冷 開始: 2000 年 3 月 13 日 通電実験開始 : 2000 年 4 月 11 日 通電実験終了: 2000 年 8 月 18 日 冷凍機停止: 2000 年 8 月 29 日

2.ロシア・コイル（ロシア担当、 TF コイルを目的としたチタンの薄肉コン ジットと $\mathrm{Nb}_{3} \mathrm{Sn}$ を使用した 1 層コイル、TF インサート・コイルとも呼ぶ) 上記 1.の CS インサート・コイルを取り出し、その位置にロシア・コイル を設置した。

コイル到着: 2001 年 5 月 25 日 予冷開始: 2001 年 8 月 20 日 通電実験開始 : 2001 年 9 月 17 日 通電実験終了：2001 年 10 月 19 日 冷凍機停止: 2001 年 11 月 7 日

3. ニオブァルミ・コイル（日本担当、 $\mathrm{TF}$ コイルを目的とした $\mathrm{Nb}_{3} \mathrm{Al}$ とステ ンレスの薄肉コンジットを使用した 1 層コイル、ニオブアルミ・インサー ト・コイルとも呼ぶ)

上記 2.のロシア・コイルを取り出し、その位置にニオブアルミ・コイルを 設置した。

コイル到着: 2001 年 1 月 8 日

予冷開始: 2002 年 3 月 4 日

通電実験開始 : 2002 年 4 月 3 日

通電実験終了：2002 年 5 月 2 日

冷凍機停止: 2002 年 5 月 17 日

ると、偏流によるクエンチを完全に押さえられる保証は なかった。CS モデル・コイルの実験では結果として偏流 によるクエンチは全く起こらず、予定通りの定格パルス 運転が行えた。これはモデル・コイルの最大の成果であり、

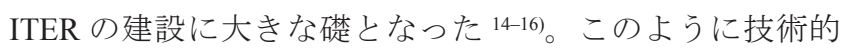
課題は多くあったものの、結果としてそれを克服できた。

CS モデル・コイルはその内側に 1 レイヤー（層）の ソレノイドが入るように設計してあり、このソレノイド を $13 \mathrm{~T}$ で試験することが可能になっている。CS モデル・ コイルの日本担当分は低磁界領域であるので、日本は CS インサート・コイルを製作しモデル・コイルと同時に 13 $\mathrm{T}$ の実証実験を行った。これらのコイルの那珂研究所へ の到着日と実験期間を Table 6 に示す。この Table には他 に、 $\mathrm{TF}$ コイル導体を目的としたチタンの薄肉コンジット と $\mathrm{Nb}_{3} \mathrm{Sn}$ を使用したロシア製コイル ${ }^{17)}$ の実験期間、同じ く $\mathrm{TF}$ コイル導体を目的として $\mathrm{Nb}_{3} \mathrm{Al}$ を使用した日本の二 オブアルミ・コイル ${ }^{18)}$ の経緯も示した。何れも直流磁界 で $13 \mathrm{~T}$ の作動を実証している。

上記の R\&D 結果と建設する ITER とを比較してみると 次のようである。CS モデル・コイルはレイヤー巻であっ たが、実機のCS コイルはパンケーキ巻となった。厚肉 
コンジットは CS モデル・コイルでは INCOLOY908 を用 いたが材料コストと熱処理雰囲気の難点から、後に記す 原研が企業と共に開発したステンレスとなった。従って、 $\mathrm{SAGBO}$ の回避に成功したが材料の変更によりその技術は 休眠に入った。

$\mathrm{TF}$ コイル用として歪に強い超伝導材の $\mathrm{Nb}_{3} \mathrm{Al}$ の利用を 日本は主張し、インサート・コイルとしてその技術を立証 したが、その技術が各極に普及していなかったため ITER では採用されなかった。薄肉コンジット材としての原研が 発案したチタンに関しても、ロシアがこれをインサート・ コイルとして作り技術実証したが同様の結果となった。

長期間を要する重厚な開発プロジェクトでは、このよ うに同じコンポーネントに対して競って複数の開発を行 い、最終的にはその中から一つを選ぶ手法が取られる。結 果として技術的に全ての手法が成功しても、幾つかは利用 されないのは致し方がないのかと思われる。

$\mathrm{CS}$ モデル・コイルの実験場所としてその設備を準備す る義務があった原研は、 $5 \mathrm{~kW}$ の大型ヘリウム冷凍機、500 $\mathrm{g} / \mathrm{s}$ の超臨界圧ヘリウム・ターボ・ポンプ、大電流の電流 リード、制御系コンピュータとそのソフト等 ${ }^{19,20)}$ を開発・ 整備した。これらは CS モデル・コイルを実験する半年に 及ぶ昼夜の長期間の運転に耐え、他極から実験に加わった 研究者達がこれを賞賛するばかりでなく、その構築過程を 研究所と企業の効率良い作業の手本として認知した。この ようにコイルのみでなくその作動に不可欠な周辺先端機器 の重要性にも大いに注目する必要があると思う。

\section{3 TF モデル・コイルの R\&D}

$\mathrm{TF}$ モデル・コイルの幹事極は欧州で実施場所はドイツ のカールスルーエ研究所と決まった。TFコイルの最大磁 界はプラズマからの要求によって少なくても $13 \mathrm{~T}$ という のが設計以前の相互理解であった。この R\&Dの難しさ は、最終寸法の TF コイルに対してどのような寸法のモデ ル・コイルを作れば工学的な実証になるかという課題であ った。これは導体についてもその寸法や電流值の相似性 の点から同様である。他方、R\&Dのモデル・コイルは一 つであり、それ自身では $13 \mathrm{~T}$ までの磁界を得ることがき でないから磁界を印加するコイルが必要となり、このコイ ルも小規模のものでは全く意味をなさないことは自明であ った。ITER に限らずこの課題はトカマク方式における TF コイルの R\&D における宿命的難題であった。

カールスルーエ研究所はかつて LCT 計画 ${ }^{8)}$ に参加し、 中規模卜ロイダル・コイルで D 型の LCT コイル一つを保 有しておりこれを磁界印加コイルとして使用することを提 案した。TFモデル・コイルとして実寸導体を用いてこの 磁界印加コイルとほぼ同じ寸法のレーストラック型コイル を作り、この二個のコイルを接して組み合わせて $9 \mathrm{~T}$ の発 生を実証するということであった。磁界の発生值が低いこ とと、実機のように不均一に加わる電磁力の模擬ができな
いことの二点から、専門家会合では R\&D の意義について 一時かなりの議論があった。しかし、 $\mathrm{Nb}_{3} \mathrm{Sn}$ による非円形 コイルの製作実証の必要性と予算的に厳しい条件とをみて $\mathrm{TF}$ コイルの R\&D については他に名案がなく、結局幹事 極の提案を容認する以外なかった。結果として、TF モデ ル・コイルの製作は欧州のみの作業となった。これを補う ものとして、先に記述した CS モデル・コイルを使って、 $\mathrm{TF}$ 導体を巻線したインサート・コイルを $13 \mathrm{~T}$ で実験する ことになり、総合的にはバラエティーのある開発になった。

EDA の当初の設計では TF コイルはレイヤー巻きと決ま ったが、実寸導体でのこの巻き方によるモデル・コイルの 加工は不可能とみられ、結局議論の末に単層パンケーキ巻 きで導体はラジアル・プレートに納めることで了承された。 結局、この R\&D では実機と同じ導体でコイルの製作技術 の習得がその主目的となり、それを $9 \mathrm{~T}$ の定常磁界で実証 するという位置付けとなった。この TF モデル・コイルの 実験は Table 1 にあるようにCS モデル・コイルの実験よ り 2 年ほど後になった。それでもこの実験は当初目的を上 回る $10 \mathrm{~T}$ を達成して、その詳細は論文とまとめて報告さ れている ${ }^{21)}$

$\mathrm{TF}$ コイルの R\&D については、13 T までの導体性能は CS インサートで実証しており、非円形コイルの製作につ いては TF モデル・コイルで習得しそれを $10 \mathrm{~T}$ で実証して おり、両者を持ってして実機の製作が可能という判断とな った。全てをモデルで実証できないエンジニアリングが存 在するという事実と、他方 R\&D の始まりからの技術の成 長を今後に外挿してみると、実機に対してこのような締め くくりは納得ゆくものと考えられる。

\section{4 低温構造材料}

核融合炉においてコイルには高磁界と寸法が大きいの で、高い応力が発生し、これを構造材料で支持する。この 応力值は従来の機械設備では実績のない高い值となる。し かもその使用温度は絶対温度 $4 \mathrm{~K}$ である。この構造材料の 重要性を 1980 年前後に認識した原研は実験炉の構造材料 の目標值を設定し、4 K における降伏応力值は $1,200 \mathrm{MPa}$ 以上、破壊勒性值は $200 \mathrm{MPa} \sqrt{\mathrm{m}}$ 以上とした。これを国外 に発表したら、この範囲は原研の名前を取りJAERI-BOX と名づけられた。当時では目標值が高過ぎ、達成不可能と 言う声も国外から多くでた。原研は、この目標を達成する ために、国内の複数の鉄鋼メーカーと共同研究協定を締結 し、新鋼種の開発を実施した。この研究では、鉄鋼メーカ 一が試作溶解した鋼材を、原研が整備した低温評価試験設 備で評価するという試行錯誤を繰り返し、当初は数十あっ た鋼種を上記の条件を満足する数種に絞った。この作業に 米国が関心を示して、材料開発、低温での特性評価法、お よび構造設計基準を一体にした日米核融合協力のワークシ ヨップを持つことになった。この会合を何度も行い、そこ で国内の大学・研究機関も参加して議論を行った。その結 
果として、液体へリウム中の引張試験法は日本では JIS に、 米国ではASTMに平行して規格化された。また、破壊勒 性試験については、この活動が終了した後に原研の提案に よって日本でJIS に規格化され、対応する米国の規格は見 られない。

その後に展開した ITER の工学 R\&D において、原研で 開発した低温構造材料の評価試験作業が R\&D 項目として 我が国に認められた。この R\&D では、鋼種を決めて試作 費によって実機に使う規模の溶解をメーカーに依頼して、 その鋼材の評価を行った。この時点では、上に示した米国 の活動はなくなり欧州に僅かに類似した作業が見られるの みであった。

電磁力を構造材料に伝達するには、電磁力発生の近く に構造材料を配置することが効率的である。この為に導体 に厚肉コンジットを付属させたり、あるいは個々の導体が 収まるラジアル・プレートを設けたりしていることはこれ までの説明に示した通りである。TF コイルには PF コイル からの磁界によって転倒力が加わるので、一つの TF コイ ルの剛性も高めるとともに、TFコイルを結合することで、 コイルの相互間の力を支持する必要がある。更に PF およ び CS コイルの重力支持も全面的に TF コイルに持たせて おり、この点からも厚肉のコイル・ケースが必要となる。 Fig. 5 は、ITERの設計チームが提案した実機 TF コイル. ケースの応力值の分布に準じたクラス分けと、これに対応 して日本が製造する鋼種を示している。最も応力值が高い $\mathrm{TF}$ コイルの直線部をクラス 1 として、ここには日本が開 発した JJ1 と呼ばれる $12 \mathrm{Cr}-12 \mathrm{Ni}-10 \mathrm{Mn}-5 \mathrm{Mo}-0.24 \mathrm{~N}$ の鋼材 の鍛造品を実機に使うことに決まった ${ }^{22)}$ 。また、クラス 2 および 3 に対応する部分に $316 \mathrm{LN}$ ステンレスで窒素含有 量が 0.17 から $0.22 \%$ ののを使用する。後者に使用する 熱間圧延板では、この窒素量は規格範囲内であるが、前者

\section{構造材料の分類}

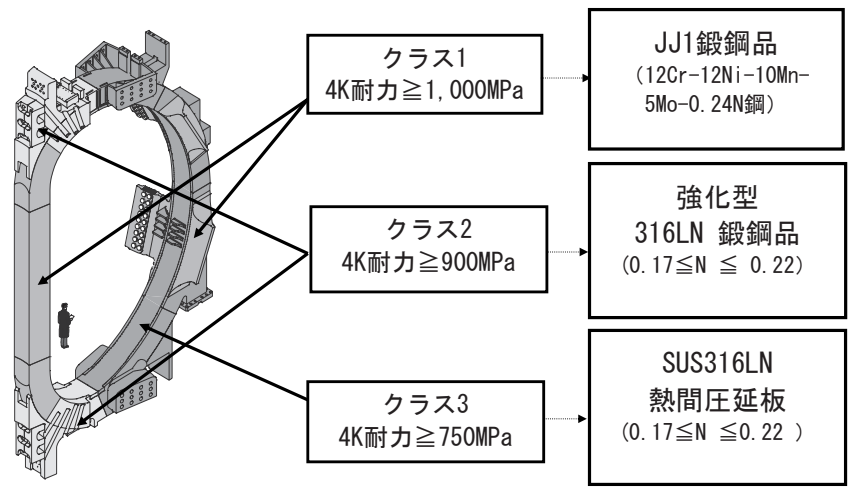

Fig. $5 \mathrm{TF}$ コイルの応力分布に従う構造材料の分類とそれ に対応する構造材料

Classification of TF coil structure depending on stress distribution and corresponding materials.
に使用する鍛鋼品では規格より多い窒素含有量となる。

ラジアル・プレートでは、応力が高いところでは上記ク ラス 2 と同じ材料を用い、応力の少し低い部分では窒素 の含有量が 0.07 から $0.12 \%$ のもの使用する予定である。 これら高窒素 316LN の厚板材の製作経験は国内でもない ため、実機規模の材料試作とその極低温機械特性の評価を 実施し、その結果と製造に問題がないことが確認されてい る。ITER では TF コイル 1 個の総重量が $300 \mathrm{t}$ の中、構造 材料としてのケースが $200 \mathrm{t}$ でラジアル・プレートが $60 \mathrm{t}$ であり、このことからも構造材料が重要な役割を担ってい ることがわかる。

導体に付加される厚肉コンジット材では、 $\mathrm{Nb}_{3} \mathrm{Sn}$ が $650{ }^{\circ} \mathrm{C}$ で 200 時間の最終熱処理により生成されるので、 この熱処理によりその機械的特性が劣化してはならな い。CS モデル・コイルで使用したコンジット材である INCOLOY908 は ITER のCS コイルに適用にならない理由 は先に記した。CS コイルにはこれに代わって、日本が開 発し上記の要求を満足する JK2LB と呼ぶ $22 \mathrm{Mn}-13 \mathrm{Cr}-7 \mathrm{Ni}-$ $1.0 \mathrm{Mo}-0.12 \mathrm{~N}$ で若干のホウ素入りの高マンガン・ステンレ ス鋼を用いることに決定した。

ITER 建設の分担においてそれまでの日本の特色あるコ イルの構造材料開発は決定打となり、結果としてコイルの 構造材の全部を日本が供給することに決まった。目標を持 って長年継続的に地道に開発を行ってきたことが有効に結 実した例と言えよう。

\section{ITER 建設へ向けて}

ITERの管理費と設備費とを合わせた総建設予算は 3,577.7 kIUA である。ここでk EDA の開始時に決めた ITER 特有の単位で当時の $1 \mathrm{k}$ 米ド

Table 7 ITER の建設において超伝導コイルの調達の配分割合 Procurement allocation for construction of ITER

1. ITER 全体に対する超伝導コイルの費用と調達の分担割合 総額に対する超伝導コイルの費用（冷凍系含まず）２6\% 超伝導コイルの内で日本の分担 $\quad 40 \%$ 欧州の分担 $\quad 23 \%$ 中国の分担 $\quad 15 \%$ ロシアの分担 $\quad 8 \%$ 米国の分担 $7 \%$ 韓国の分担 $5 \%$ 共通資金 $2 \%$

(インドの超伝導コイルの分担はないが、関連する冷凍配管および電源 を担当する)

2. 超伝導コイルの中で日本が分担する項目とその項目内での分担割合 CS コイル導体 $100 \%$ $\mathrm{TF}$ コイル導体 $25 \%$ $\mathrm{TF}$ コイルの構造材（ケースとコイル間支持構造物） $100 \%$ $\mathrm{TF}$ コイル巻線・製作の作業 19 個（予備コイル 1 個含む）の中 9 個 (PF 導体、 $\mathrm{PF}$ コイル、補正コイル、計測素子等は、日本が配分を受け ていないので、ここでは項目として記述していない) 
ルに対応するという了解である。その後も開始時の為替レ ートで固定して換算されている。

2005 年 12 月に炉コンポーネントの調達の配分が決まっ た。超伝導コイルのコストが全建設費に対する割合とその 中での日本の配分は Table 7 に示すとおりである。日本が 担当する超伝導コイルは全建設コストの $10 \%$ を超える重 要な作業である。

Table 7 の下半分は超伝導コイルの項目において日本が 関係する部分を取り出したものを示す。ここではコイルを 支援する極低温機器およびその制御システムは、仕事の区 分上コイルと切り離して設備の分類に入っている。この区 分はこれまでの R\&Dの現場の見方、つまり大型へリウム 冷凍機、超臨界圧ヘリウム・ポンプ等は先端開発品である という考え方とは異なっている。ITER 建設では冷凍機と ポンプを含むプラントは欧州が、冷凍配管とその付属品は インドが担当する。担当の極内部で製作できない場合は、 その極は製作可能な他極から購入して ITERに納入すると いうことになる。

超伝導コイルの中での配分については、資材の供給と 製作とが分離されている。日本が供給するCS コイル導体 100\%を米国が巻線してコイルに仕上げて現場に持ち込む。 $\mathrm{TF}$ コイル導体に関して日本は $25 \%$ 分担し、9 個の $\mathrm{TF} コ$ イル巻線とコイル・ケースへの収納作業を行ってサイトに 持ち込む。9 個の $\mathrm{TF}$ コイルは全体の半分なので日本には 他極の $\mathrm{TF}$ コイル導体が持ち込まれることになる。 $\mathrm{TF} コ$ イルの構造材の全部を日本が供給するが、そのうち半分は 欧州に持ち込まれる。

超伝導コイル以外で日本が担当する大きな項目は、外 側ダイバータとブランケット遠隔保守機器の夫々 $100 \%$ 分 がある。これ以外の細かい項目すべての費用とこの 2 つの 項目の費用とを足し合わせてもコイルの費用の $40 \%$ であ る。これから、超伝導コイルの重要性とそれに対応する費 用のウエイトを理解できよう。

ITERの建設は2007 年後半に着手され、その完成まで に 10 年の月日を要する。完成当初は水素プラズマで装置 の調整を行い、その後トリチウム - 重水素の短時間燃焼プ ラズマの研究を 10 年続ける。その後に長時間燃焼実験に 着手するという長期にわたる計画である。

\section{6. おわりに}

ITERの姿とそれまでの R\&D との関係、更に建設の分 担についての概略を超伝導コイルの側面から理解して頂け たことと思う。

核融合炉のコンポーネントは多岐にわたっており、そ の全ての説明と理解は単純ではない。コンポーネントの幾 つかを取り出してR\&D を比較してみても、それらの手法 が類似といえるものは殆どないと言えよう。超伝導コイル は他の開発課題と干渉する部分がないので、開発が行いや
すいと言える。しかし、TFコイルの R\&D ではスケール ダウンしたモデルが実機の一部分しか実証できないという 宿命的難題をもっていることを先に記した。工学的開発と は本来そのようなものであろう。

ここで実用炉におけるブランケットの開発の例を考え てみると、照射を受ける構造材料、増殖材料の選択と燃料 収集率の向上、エネルギー変換のため泠媒の種類とその引 き回し手法等多くの課題がある。これらを一つの R\&D で 同時に解決できないし、核然焼の到達のみを目的とした実 験炉では差し当たり遮蔽ブランケットの領域に止め、核然 焼が手中に入った後段において増殖ブランケットの設置の 可能性も検討されている。

国際協力作業のタイプとして、同一コンポーネントを 分割して納期や品質を競うコンクール方式と、コンポーネ ントを製作の縦の流れに分けてその流れに従って国を渡り 歩いて製作しこれを集めて建設する協同組合方式の 2 つが ある。ITERの R\&D は後者であり、建設は両者の混合で ある。先にコンクール型の協力作業を経験していた著者ら は、ハードウエアの半加工のものが国境を越えて往き来す る手法には懁疑的であった。EDA で共同チームにヨーロ ッパから参加したメンバーは、協同組合方式は欧州共同体 内では産業でも開発でも活発であり、この手法をITERに 適用し世界に広めることを語っていた。この手法による工 学 R\&D に立ち向かったが、CS モデル・コイルの成功に より協同組合方式による国際協力で ITER の建設が可能で あることを認知した。

ITER という大きな国際協力の枠においてアジアで急速 に成長しつつある三力国が参加した。従来追いつけの精神 と手法で作業を行ってきたわが国は後に続く国々に開発技 術の開示あるいは移転を行うという立場になった。管理運 営という点からもここに新たな成長が期待されている。

核融合卜カマク方式で、韓国、中国、インドでプラズ マ物理研究を目的とした規模の装置が超伝導コイルを使用 して建設されている。国内ではJT-60 の改造が超伝導コイ ルの利用によって考えられている。これらはITER ほど大 規模ではないが、磁気核融合装置が全面的に超伝導利用の 時代に入ったことを現している。

著者らは長年 ITER の開発活動に携わり、原子力機構内 外の多くの方々のご鞭撻・ご支援を受けたまわってきて今 日があることに深く感謝しています。CS モデル・コイル の開発作業の実務を担当した原研・核融合炉工学部の辻博 史次長が ITERの建設サイトが決まる前に他界したことを 残念に思います。ITERの R\&D ハードウエアの製作に当 たって頂いた企業、共同して実験研究を行った大学・国立 研究機関に誌面を借りて御礼申し上げます。日頃のご指導 を頂いている原子力機構・核融合部門の常松秀俊部門長に 謝意を表します。 


\section{参 考 文 献}

1) R. Aymar: "ITER R\&D, design overview," Fusion Eng. Design 55 Issue2-3 (2001) 107-118

2) “ITER Engneering Design,” J. Plasma Fusion Res. 78 Supplement (2002)

特集「ITER 工学設計」、プラズマ・核融合学会誌 78 増刊号 (2002)

3) "The Summary Report on Engineering Design Activities in the International Thermonuclear Experimental Reactor (ITER) Project," NIHON-GENSHIRYOKU-GAKKAI SHI 44 (special issue) (2002) 1-89

特集「ITER 工学設計活動報告」、日本原子力学会誌 44 (2002) 1-89

4) S. Shimamoto: "Superconducting magnet development for fusion at JAERI," Cryogenics 25 (1985) 171-177

5) S. Shimamoto, et al.: "Development of superconducting pulsed poloidal coil in JAERI," Cryogenics 30 (1990) 23-28

6) "Toroidal Coil Development for Fusion - LCT and the Cluster Test Facility,” TEION KOGAKU 19 No. 2 (special issue) (1984) 特集「核融合トロイダル・コイル開発 - LCT、クラスター・ テスト装置」、低温工学 19 No. 2 (1984)

7) S. Shimamoto: "Evolution and final results; international collaboration of superconducting toroidal coil development," TEION KOGAKU 24 (1989) 134-142

島本 進:「超電導トロイダル・コイル開発の国際協力 “LCT 計画”の展開と成果」、低温工学 24 (1989) 134-142

8) “THE IEA LARGE COIL TASK," Fusion Eng. Design 7, No. 1 \& 2 (special issue) (1988)

9) “ITER Design Report,” J. Plasma Fusion Res. 73 Supplement (1997)

特集「ITER 設計報告」、プラズマ・核融合学会誌 73 増刊号 (1997)

10) “ITER Technology R\&D," Fusion Eng. Design 55 Issue 2-3 (special issue) (2001)

11) Y. Takahashi, et al.: "Experimental results of the $\mathrm{Nb}_{3} \mathrm{Sn}$ demo poloidal coil(DPC-EX), " Cryogenics 31 (1991) 640-644

12) N. Koizumi, et al.: "Current imbalance due to induced circulation current in a large cable-in-conduit superconductor," Cryogenics 36 (1996) 409-414

13) 小泉徳潔: 「変動磁界中の強制冷却導導体の偏流現象に関 する研究」、JAERI-Reseach99-076 (日本原子力研究所 - 研 究報告書) (2000)

14) "Test Results of ITER-CS Model Coil and CS Insert Coil," TEION KOGAKU 36 No. 6 (special issue) (2001)

特集「ITER-CS モデル・コイルと CS インサート・コイル の実験結果」、低温工学 36 No. 6 (2001)

15) H. Tsuji, et al.: "ITER R\&D: magnets: conductor and joint development," Fusion Eng. Design 55 (2001) 141-151

16) H. Tsuji, et al.: "ITER R\&D: magnets: central solenoid model coil," Fusion Eng. Design 55 (2001)153-170

17) “Test Results of ITER-TF Insert Coil," TEION KOGAKU 37 No. 10 (special issue) (2001)

特集「ITER-TF インサート・コイルの実験結果」、低温工学 37 No. 10 (2002)

18) “Test Results of $\mathrm{Nb}_{3} \mathrm{Al}$ Insert for Fusion Reactor," TEION
KOGAKU 38 No. 8 (special issue) (2001)

特集「核融合炉用 $\mathrm{Nb}_{3} \mathrm{Al}$ インサート・コイルの実験結果」、 低温工学 38 No. 8 (2003)

19) S. Shimamoto, et al.: "Construction of ITER common test facility for CS model coil," IEEE Trans. Magn. 32 (1996) 3049-3052

20) T. Kato, et al.: "CS model coil test facility," TEION KOGAKU 36 (2001) 315-323

加藤 崇ら：「CS モデル・コイル試験装置」、低温工学 36 (2001) 315-323

21) A. Ulbricht, et al.: "The ITER toroidal field model coil project," Fusion Eng. Design 73 (2005) 189-327

22) H. Nakajima, et al.: "New cryogenic steels and design approach for ITER superconducting magnet system," Proc. of 10th Int. Conf. on Nuclear Eng., ICONE10-22674 (2002) 1-8

23) T. Kato, et al.: "Avoidance method study for SAGBO cracking during heat treatment of a ITER CS model coil conductor using INCOLOY 908 Jacket,” Adv. Cryo. Eng. 44 (1998) 9-15

\section{島本進}

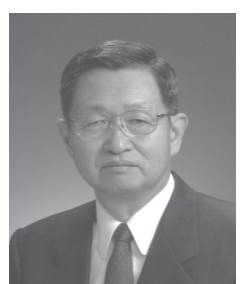

1938 年生。1961 年東北大学電気工学科卒業。 通産省電子技術総合研究所、フランス原子 カ庁サクレー原子カセンター主任研究員、 日本原子力研究所核融合工学部長 - 那珂研 究所長を経て, 1997 年東北大学工学研究科 教授 (電気・通信工学専攻)。2001 年同教 授退官後、日本原子力研究開発機構研究嘱 託、成蹊大学・明治大学の講師 ( ‘技術者倫理” 担当)。科学技術庁長官賞 '科学技術功労者, ・電気学会進歩賞 日本原子力学会特賞 - 低温工学協会大山記念賞を受賞。電気学 会および低温工学協会会員。工学博士 (東北大学)。

\section{高 橋 良 和}

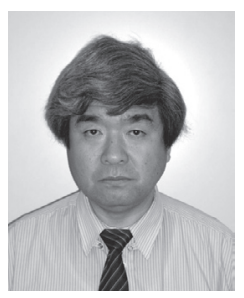

1952 年 1 月生。1975 年立教大学理学部物理 学科卒業。1977 年千葉大学理学研究科修士 課程修了。1980 年日本大学理工学研究科博 士課程修了。同年 4 月日本原子力研究所 (現 在の原子力機構) 入所、核融合工学部超電 導磁石研究室に勤務。2001 年 4 月より ITER 開発室 (共同設計チーム) に所属。主として、 超電導パルス・コイルの開発、超電導導体の 電気・熱流体解析、交流損失の研究に従事。低温工学協会、日 本物理学会、電気学会、プラズマ核融合学会会員。理学博士。

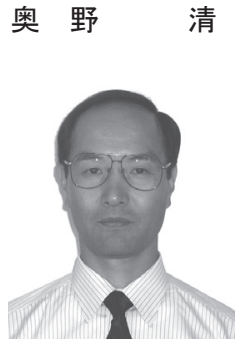
会会員。
1953 年 8 月 27 日生。1977 年東京工業大学 物理学科卒業。1979 年同大学大学院原子核 工学科修士課程修了。同年 4 月から日本原 子力研究所に勤務。現在、日本原子力研究 開発機構 ITER 超伝導磁石開発グループ・リ ーダー。主として核融合炉用大型超伝導パ ルス・コイルの研究開発、ITER 設計活動に 従事。低温工学協会、プラズマ・核融合学 